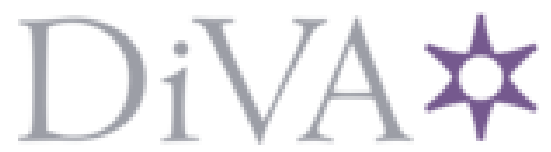

http://www.diva-portal.org

This is the published version of a chapter published in Neoliberalism and the Political Economy of Tourism.

Citation for the original published chapter:

Ioannides, D., Petridou, E. (2016)

Contingent Neoliberalism and Urban Tourism in the United States.

In: Jan Mosedale (ed.), Neoliberalism and the Political Economy of Tourism (pp. 21-37).

Routledge

N.B. When citing this work, cite the original published chapter.

Permanent link to this version:

http://urn.kb.se/resolve?urn=urn:nbn:se:miun:diva-27005 


\title{
Chapter 2 \\ Contingent Neoliberalism and \\ Urban Tourism in the United States
}

\author{
Dimitri Ioannides and Evangelia Petridou
}

Academic debates regarding tourism's ascendancy as key for urban transformation and revival in a post-industrial era have become increasingly popular for the better part of the last two decades (Judd, 1995; Hoffman et al., 2004; Judd, 2004; Judd, 2006; Gladstone and Préau, 2008; Ioannides and Timothy, 2010). Nevertheless, the extant scholarship on urban tourism barely examines this phenomenon in tandem with the "critique of neoliberalism" (Hall and Page, 2012: 16; see other chapters in this volume), which currently preoccupies many human geographers. Highlighting this point, Hall and Page indicate just a handful of studies like Clancy's (1998) examination of neoliberalism's interlinkages to tourism's development context. Hall (2006) himself discusses how urban entrepreneurialism's marriage to neoliberalism ideologically validates "place-competitive re-imaging strategies including the hosting of sports megaevents" (ibid.: 64).

Though Hall's (2006) discussion on the inter-linkages of visitor-oriented mega events to urban neoliberalism falls within the realm of a broader political economy approach in tourism geography as advocated by Britton (1991) (see also Debbage and Ioannides, 2012; Bianchi, 2012; Mosedale, 2011), recent writings on urban tourism exhibit limited explicit awareness of social scientists' strides relating to neoliberalism's contingent nature (Brenner and Theodore, 2002; Keil, 2002; Jessop, 2002; Peck and Tickell, 2002; Wilson, 2004; Hackworth, 2007; Sternberg, 2012). If anything, most observers discussing tourism's phenomenal growth within cities only implicitly tie this to a generic form of neoliberal ideology, failing to account for the "contextual embeddedness of neoliberal restructuring projects insofar as they have been produced within national, regional, and local contexts defined by the legacies of inherited institutional frameworks, policy regimes, regulatory practices, and political struggles" (Brenner and Theodore, 2002: 351).

This chapter focuses on urban tourism's evolution in the US since the beginning of the neoliberal era. Upfront, we remind the reader that over the last quarter century or so the transformation of cities - especially their central parts into standardized tourism enclaves (Judd, 2004) has occurred in phases mirroring the shift from "proto" to "roll-back" and eventually "roll-out" neoliberalism as postulated by Peck and Tickell (2002). Thus, the late 1970s and 80s witnessed 
indiscriminate investments in mega-projects such as dockland redevelopments, convention centres, festival market halls, and sports stadia whereby the public sector assumed the role of facilitator (e.g., by establishing public-private partnerships), thus circumventing traditional regulatory instruments and citizen participation. During the period of roll-out neoliberalism in the 1990s, the private sector's role in the redevelopment process became far clearer while the public sector entered its revanchist period (Smith, 1998; MacLeod, 2002). The latter effectively amounted to efforts in New York's Times Square to enhance the quality of life of residents and visitors by disciplining the elements perceived as harmful to the city's new image (i.e., the homeless, immigrants, and unwanted land uses like red light districts).

The story does not end here. Rather, over the last 15 years or so we have witnessed a period marked by initiatives (sometimes emerging at the grassroots) to revitalize and commodify run-down neighbourhoods and industrial districts beyond the standardized centre city tourist bubbles (Lloyd, 2002; Judd, 2004) We caution that this movement to develop so-called "neo-bohemias", which links to Richard Florida's (2002) "creative class" concept, continues to rest within neoliberalism's boundaries since it happens within the realin of the de facto competition between cities, persists on placing the burden of revitalization on non-state actors, and continues to operate in a manner that excludes undesirable persons and land uses.

At this juncture, we emphasize two points: first, though we agree with neoliberalism's hypothesized evolution since the 70 s, the process, which has influenced tourism development in US cities, cannot be neatly compartmentalized in clear stages as the aforementioned discussion may suggest. After all, social processes tend to be messy with phases overlapping. Second, to meet the challenges of devolution imposed in a neoliberal regime, various local govemments react in widely divergent ways (Elander, 2002). History and geography matter, meaning neoliberalism is marked by a high degree of contingency as it plays out in various localities. For instance, cities' political priorities are reflected in their institutional structure, which will be different in places that make catering to private businesses their main concern compared to those that prioritize social justice. "Urban policy choice is thus embedded in a structural framework that allows or facilitates some choices more than others (Pierre, 2011: 17). Further, even cities with identical priorities employ different strategies to achieve them since the neoliberal project is moulded by local (place-bound) idiosyncrasies.

This chapter begins with a brief description of urban redevelopment and tourism's ascendancy in US cities since the beginning of the neoliberal era in the late 1970s. After reminding the reader of the effects of the transition from roll-back to roll-out neoliberalism we focus on a relatively new phenomenon that is gathering steam in many metropolitan areas around the country; namely the appearance of neo-bohemian neighbourhoods. We see these places as ones where the concept of contingent neoliberalism is becoming most evident.

\section{Setting the Scene}

Back in the 1980s it had become strikingly evident that numerous cities throughout the US had experienced the amalgamated result of post-Second World War sociopolitical forces, including the 1949 "Urban Renewal" Act (Title 1 of the 1949 Housing Act), the 1956 Federal Highway Act, the Civil Rights Movennent of the 1960s, widespread decline of manufacturing, and the gradual erosion of federal funding for cities (Beauregard, 1998). These factors had precipitated, albeit to varying degrees, the mass exodus, first of white middle class residents and increasingly their jobs to the suburbs, leaving behind within the inner cities entire swathes of boarded up commercial districts, abandoned housing stock and pockets of ultra-low income neighbourhoods, and decaying infrastructure. This loss of people and jobs eroded the inner cities' tax base hurling these places into a downward economic spiral.

Within the inner part of the "average Ainerican city" of the 1980s the likely land uses lingering on were certain governmental services (e.g., municipal offices, the State welfare office, or the Department of Motor Vehicles), thrift stores, soup kitchens, buildings converted into SROs (single room occupancy) or boarding houses. Occasionally, a museum or a theatre, most likely in a state of disrepair, reflected the vestiges of a bygone era. In many respects, unless one had an important reason for being downtown (like renewing one's driving license) there was little reason to visit.

Nowadays, if one were to revisit one or more of the aforementioned "average American cities", one would encounter a remarkably transformed seting. The vacant commercial spaces have likely transformed into niche-oriented clothing boutiques, specialized bookstores, an iridependent movie theatre, jazz bars, restaurants (from fast food joints to expensive gourmet level establishments), coffee houses, or a microbrewery. New benches and street lamps, planter boxes, red brick sidewalks, bicycle lanes and parking racks, not to mention various types of traffic calming create an inviting streetscape. All of these services and amenities have served to resuscitate these once-barren urbanscapes by drawing new residents as well as numerous visitors many of whom come in from the highly predictable suburbs (Beauregard, 1998).

To explain the remarkable transformation of US cities, Hackworth (2007) adopts David Harvey's "spatial fix" as a "useful schema for understanding the connection between political restructuring and physical landscape change" (ibid.: 79). Hackworth contends that the spatial fix for generating economic growth and new jobs in the aftermath of the Great Depression and World War Il until the 1970s was "centrifugal" (ibid.: 80), mirrored by widespread suburbanization and the growth of the Sunbelt, arising through govemment-sponsored programs favouring enhanced homeownership, highways, and the automobile. This spatial fix was undoubtedly anti-urban, resulting in wide-scale inner-city decline throughout the country (Gillette, 2010). Yet, by the mid-1970s, this particular spatial fix could not deal with the problems arising from the 1973 oil crisis, the massive downturn 
in the fortunes of the manufacturing sector, and the erosion of federal funding. Hackworth asserts that:

Investors scrambled to find more productive outlets for their capital. It is little surprise that this period prompted a tremendous switch of capital to the secondary circuit, of which the commercial built environment is one significant part. As industrial decline had been in place for several decades prior to 1973 , it made little sense to swim upstream, as it were, by reinvesting in the American industrial infrastructure. The most profitable returns were to be made in the commercial property market. With the commercial real estate growth in the suburbs (shopping malls) beginning to taper off by the 1970 s, the blighted downtown suddenly became an attractive investment possibility. A switch from the industrial infrastructure of the primary circuit to the downtown commercial real estate of the secondary circuit ensued with vigor. The older urban cores of the industrial Northeast were the first to experience the state assisted return of capital in the form of festival marketplaces and, later, office complexes. Boston's Faneuil Hall, Baltimore's Harborplace, and New York's South Street Seaport are early examples of the capital switch 'back to the city'. (2007: 152)

The reorientation of the spatial fix was in itself inextricably linked to neoliberalism's ascent in its proto and roll-back guise (Peck and Tickell, 2002; see introductory chapter in this volume) that began already in the mid-1970s and gathered steain during the Reagan years, transforming the American CBD into a landscape, among others, for visitors but also new residents and businesses. Criley (quoted in Hackworth, 2007: 151) explains the CBD was especially suited in its role as "circus", a space of visitor consumption, making up for the decline and eventual loss of production of "bread", a hallmark of urban economic growth during the earlier industrial age (Judd, 1995; Clark et al., 2002).

\section{Tourism's Take-off}

A key problem associated with neoliberalism's entrenchment in its roll-back phase was the massive loss in federal funds for economically depressed urban areas. This caused local authorities throughout the US to struggle to provide basic services (Smith, 2002) resulting in intense place wars whereby communities compete to lure new business investment, households, and visitors through lucrative incentives (e.g., generous tax breaks and the relaxation of regulations) (Kotler et al., 1993; Ioannides and Timothy, 2010).

Neil Smith $(2002 ; 427)$ aptly labels such incentives - the mantra of urban redevelopment efforts throughout the country since neoliberalism's early phases - "geobribes" to footloose private capital. Often, inner city areas came under the auspices of so-called urban developinent corporations (UDCs), which were essentially public-private partnerships with complete planning and development rights within their designated area. Within UDC-administered jurisdictions, existing planning and zoning regulations were legally overridden while active involvement of citizens in the planning process was discouraged. Additionally, it was common for UDCs to exercise power of eminent doinain (compulsory purchase). The overriding aim was to facilitate the private sector's ability to redevelop these areas, many of which were blighted, leading to further investment whilst also causing trickle-down economic growth (Fainstein, 2010).

During this time, mega tourism projects became an active ingredient of urban redevelopment especially within central parts of larger cities (Fainstein et al., 2004). Even smaller cities were inspired to recreate parts of their urban fabric into visitor spaces by adapting, albeit on a smaller scale, elements that had worked in their larger counterparts (Ioannides and Timothy, 2010). The popularity of visitororiented projects for inner city redevelopment stemmed from the realization that spaces once used for industrial production, warehousing, markets, railway stations, or port facilities could easily be recycled into places of consumption. Much of this historical building stock possessed an architectural quality lacking in the banal suburban residential and commercial districts where most Americans now choose to live, go to school, work, shop, and entertain themselves. According to Beauregard (1998), since the poimt of origin of most contemporary visitors to urban areas are the suburbs, these people are often enticed by powerful feelings of nostalgia for the inner city neighbourhoods and buildings their grandparents or parents left behind some decades ago (Turner and Rosentraub, 2002).

Several reasons lie behind tourism's popularity as an urban redevelopment tool in the neoliberal era. First, while many US communities continue active smokestack-chasing by portraying themselves as business friendly, such efforts burden local residents since the generous financial incentives offered are commonly derived from taxpayers' contributions (Clark et al., 2002). Visitororiented strategies, by contrast, are often funded by the state and not the local community (perhaps matched by contributions from the private sector) while entry barriers and job-creation costs in tourism tend to be substantially lower than other economic sectors (Ioannides, 2003). Additionally, when a city develops a visitor attraction, the key rationale is not only to draw tourists but also to boost the city's image thus enhancing liveability for present residents, drawing new inhabitants, and attracting other potential investors (Turner and Rosentraub, 2002). This is the very reason many city leaders throughout the country shun a detailed feasibility analysis when projects like a ballpark are proposed (Judd, 1995). To them, the fact their city can find itself on the tourist map is enough to justify such projects regardless of cost (Ioannides, 2003).

\section{Urban Tourism in the Revanchist Era}

By the 1990s, numerous urban areas throughout the US had become spaces for visitors. Within these islands engulfed by "a sea of decay" (Judd, 1999:36) 
threats to the quality of the visitors' experience were and still are curtailed and/ or eliminated through the use of security personnel and enhanced policing as well as closed-circuit surveillance systems, better lighting, and turnstiles. Effectively, these became what Judd (2004) terms "tourist bubbles," highly regulated enclavic spaces geared entirely to the well-being of their users as long as the latter are not undesirable (Fainstein et al., 2004). Within these areas the homeless, the poor, or protesters have no place.

These tourist bubbles mirror the rise of the revanchist city (Smith, 2002), essentially amounting to the area's control "through a range of architectural forms and institutional practices so that the enhancement of city's image is not compromised by the visible presence of those very marginalized groups" (MacLeod, 2002: 602). Peck and Tickell (2002) warn, however, that this form of the neoliberal project hardly signifies the demise of the pro-economic growth agenda, demonstrating instead that rather than being a passive observer, the public sector's role has shifted and, in fact, been reanimated.

The trademarks of the public sector's new role include programs initiated by the Clinton adıninistration to reform welfare (Smith, 2002), variations of which were adopted by municipalities throughout the country. Notably, New York City "implemented the nation's largest and most successful workfare program. In exchange for welfare benefits, our 35,000 workfare participants help maintain streets, parks, and city buildings and gain experience in more than 20 city agencies" (Giuliani, 2000: 162). According to Giuliani, this step was part of a package of measures "to implement the largest and widest-ranging privatization program of any city in the country" (ibid.: 161) because he saw this as the only way for New York to be reinstalled as the world's preeminent metropolis. Variations of this theme were seen in other cities including Chicago and Indianapolis (Daley, 2000; Goldsmith, 2000).

Both visitors and residents need to feel comfortable in the areas they frequent. Arguing that the best way to induce safety is to halt crime before it begins many communities installed "zero tolerance" programs (Smith, 2001: 69). These include the Chicago Alternative Policing Strategy (CAPS), introduced in 1993 to create "safer streets for everyone" (Daley, 2000: 144) and Police Strategy No. 5, Mayor Rudolph Giuliani's effort to demonstrate no tolerance in New York City for crime nor other threatening activities in public spaces. Smith (2001) sees these programs as nothing more than social cleansing strategies. "Zero tolerance policing has encouraged race and class profiling that places a premium on street arrests of suspects while minimizing concerns about evidence" (ibid.: 71). Elsewhere, Smith (1998: 3) has argued that:

Rather than indict capitalists for capital flight, landlords for abandoning buildings, or public leaders for a narrow retrenchment to class and race selfinterest, Giuliani led to the clamor for a different kind of revenge. He identified homeless people, panhandlers, prostitutes, squeegee cleaners, squatters, graffiti artists ... unnuly youth as the major enemies of public order and decency, the culprits of urban decline generating widespread fear.

Ironically, enhanced regulation of public spaces in the name of protecting citizens' right to the city aided cities like New York in their gentrification efforts and, particularly, their aim to make entire areas welcoming for tourists and middleincome residents. Certainly the transformation over the last two decades of Times Square and areas surrounding it, much of it attributed to the efforts of the Disney Corporation, would not have been as effective if the red-light district and various activities and people seen by the Giuliani adıninistration as having no place there had not been forced out. Of course, as this area and others including parts of Harlem (see Hoffman, 2004) were reclaimed for visitors this meant the homeless, the poor, the unlicensed street vendors, the gypsy taxi-cabs and anyone else threatening these sanitized spaces were shoved aside, ending-up in other less fashionable districts.

On a troubling note, it is evident such revanchist behaviour on the part of city administrations shown no signs of abatement. During 2011, New York police officers undertook as many as 700,000 searches of persons suspected of engaging in an illegal activity. This was done under the policy known as "stop, question, and frisk" (Kastenbaum, 2012), which gives the right to any officer to apprehend and search any person perceived to be up to no good. Proponents of the law say it works as a deterrent to crime, citing a phenomenal lowering in the city's murder rate over the last two decades. Opponents maintain this revanchist activity amounts to nothing more than racial profiling since most of the people are apprehended are African Americans and Hispanics.

\section{Neo-Bohemias: Expressing Neoliberalism's New Phase?}

More than a decade into the new century, the effects of "roll-out" neoliberalisin within US cities are firmly set while, simultaneously, strategies associated with the earlier "roll-back" neoliberalism persevere. To be sure, the recent worldwide economic crisis have stalled many large-scale programs aimed at enhancing visitor spending but undoubtedly the transformation of cities into spaces of tourism consumption will continue into the foreseeable future.

Few would argue that downtown areas of cities like Cleveland or Pittsburgh have not taken a turn for the better if the measures for gauging this improvement are declining vacancy rates and the expansion of retailing, entertainment, and residential activities. The introduction of public safety measures within these spaces leads users (visitors or residents) to feel far less threatened than in the past. Additionally, the visitors and residents are subject to highly regulated environments in terms of the sights and facilities on offer (shops and services, many displaying well-known global corporate symbols) or signature architectural marvels, while the types of land uses and the activities the users 
of these spaces engage in are enveloped in an aura of predictability. This is precisely the message both public officials and private capital managing these enclosures wish to project.

On the surface, the proliferation of downtown tourist bubbles in so many metropolitan areas paints a depressing picture that in the neoliberal age, places are becoming increasingly alike despite striving to project their competitive uniqueness. However, according to Fainstein et al. (2004), the fact that not al urban touristic enclaves have met with the same level of success (some like Flint Michigan have notably proven major flops) (Hackworth, 2007) highlights the importance of contingency, implying that predictions of cities becoming carbon copies of each others are vastly exaggerated (Ioannides and Timothy, 2010). We should stress that although the type of neoliberal governance driving urban redevelopment throughout the country fundamentally has the singular aim to "'re-entrepreneurialize' cities physically and socially" (Wilson, 2004: 771) this hardly signifies a "one-size-fits-all" approach playing out in an identical fashion in every single locality. Rather, one has to account for the fact that "in the world of evolving places, we see a patchwork of wildly varying neoliberal governances that often barely resemble each other" (Wilson, 2004: 772).

To illustrate this point, Wilson compares the way neoliberal governance plays out in Indianapolis and Chicago. His argument is that although a neoliberal agenda drives governance in both cities, in Chicago emphasis is on becoming a global city by encouraging, for example, the high tech sector whereas in Indianapolis a far less ambitious aim, driven by local developers, is to convert the downtown into a gleaming attraction through a process that "associates capital accumulation with real-estate" (ibid.: 774). Wilson maintains that while in both cities mechanisms are in place to "discipline [their] physical, cultural, and social "infrastructure" (ibid.), both the growth engines as well as the expected outcomes differ.

Contingency's significance is also reflected in Harlem's recent revival as a visitor hot spot in New York. According to Hoffman (2004) this cannot only be attributed to forces of global capital been imposed from above. Rather, a complex layer of internal dynamics, including the area's unique rich cultural heritage, underpins this revival. To be sure, Harlem has been infiltrated by global symbols of capitalism (e.g., Disney and AOL Time Wamer) displaying revanchist activities aimed at dampening its notoriety as a crime-ridden ghetto. However, it also strongly reflects elements of its rich African-American heritage that have been incorporated in the total tourism product, setting it aside from other sterile enclaves.

Reversing his earlier opinion concerning the dominance of tourism enclaves as direct outgrowths of urban restructuring, Judd (2004) asserts that "despite the effects of globalization, cities vary significantly from one another, and they are not necessarily converging" (ibid.: 24). Referring to Boston, one of the oldest North American cities, Judd argues that despite the clear existence of enclaves like Faneuil Hall and Copley Plaza, more and more visitors delight in venturing beyond these areas, spending time in commercial, residential, and mixed-use neighbourhoods, rubbing shoulders with the locals.
The growing phenomenon of visitors seeking escape from the tourist bubbles is not confined to famous historic districts and/or upper middle class zones of only a handful of cities. Instead, more and more individuals visit gritty areas such as "transitional neighbourhoods or zones where people are on the margins of urban society" (Judd, 2004: 30). Districts like Chicago's Wicker Park and Kansas City's Westport retain elements of their past industrial heritage and, as such, are not naturally touristic (Ioannides and Timothy, 2010). However, these neo-bohemias (Clark et al., 2002; Lloyd, 2002) emit a feeling of far greater originality than the predictable downtown bubbles, precisely because they retain inuch of their original (albeit refurbished) urban fabric and, importantly, because the visitor mingles with locals representing various ages, socioeconomic levels, and ethnicities living, working, and playing.

Drawing visitors to these areas, which the American Planning Association labels "great neighborhoods" (Hinshaw, 2008: 8), is their image of uniqueness in that they commonly offer a rich mix of architectural types, an unforgettable character, and may be transit-oriented and pedestrian-friendly. There is also a preponderance of independently-owned businesses and not the clichéd national and international chain operations. Sometimes, the forces shaping the transformation of such neighbourhoods are distinctly bottom-up (at least during the early stages), differing substantially from those underpinning the stereotypical inner-city tourist bubble. They could, for instance, involve actors such as longterm residents wanting to improve their quality of life but also members of the "creative class" (Florida, 2002) including software designers, artists, and musicians. Often, these individuals become vocal advocates for the future of their neighbourhoods, which despite their anachronism deriving, for example, from their industrial heritage offer elements enabling the production and consumption of cultural amenities.

However, it is naïve to maintain that only bottom-up forces shape what goes on in these neo-bohemias. What we see in these places is the significance of contingency in the way a particular city's neoliberal, redevelopment governance structure - including instruments like historic preservation and tax incentives plays out as affected by local circumstances (stakeholders, history, politicalmotives, etc.). In the case of Chicago, for instance, the redevelopment of neo-bohemias such as Wicker Park or Pilsen was actively supported by the city's underlying aim to boost gentrification with an eye on becoming globally competitive (Stemberg, 2012). Attracting members of the creative class, for instance, to these areas was an explicit goal of strengthening the city's pursuit of becoming a centre of culture and high tech activities (Wilson, 2004).

We believe the noticeable trend in North American cities over the last decade whereby neo-bohemian neighbourhoods beyond the standardized tourist bubbles have begun attracting the attention of visitors marks a new approach in the neoliberal project, albeit one that does not replace but occurs concurrently with elements commonly associated with roll-back and roll-out neoliberalism. However, unlike, straightforward "roll-back" and "roll-out" neoliberalism, which are noticeable in 
the sterilized mega projects of rehabilitated downtowns, we recognize that in neobohemias the forces of transformation are far more opaque. In many cases, local forces (bottom-up) are apparent and yet these are not operating in a vacuum; rather they are dictated by and respond to a city's neoliberal regime - regardless of what the citywide eventual desired outcome may be - as this becomes embedded within different parts of the metropolitan area.

This can be clarified further as follows. First, neo-bohemian projects, despite their creative nature, operate within a neoliberal framework because their objectives remain anchored in economic growth and developinent. However, the quest to attract businesses has probably shifted to a quest to attract cultureconsuming individuals and visitors. Second, neo-bohemian projects are more localized in focus. The emphasis is on a neighbourhood, not the city at large; on the locally owned art gallery instead of a mega-museum, and on everyday experiences instead of staged escapism. The further devolution to the inicro-local has the potential to make local contingencies even more evident. For example, although both Wicker Park and New York City's DUMBO (Down Under the Manhattan Bridge Overpass) neighbourhood are places of consumption, they are two very different neighbourhoods historically, demographically, politically, and economically. This attention to the micro-local can serve as a metaphor understanding local contingencies, especially if juxtaposed to the earlier, more monolithic stage of investing in tourist bubbles.

Arguably, the proliferation of such neighbourhoods, many of which are lauded as success stories, causes tensions. To begin with, their popularity ensures these places regularly attract the attention of global capital, which seeks to derive a share of the economic spoils by locating a facility in their midst. However, it is not unusual for this capital to encounter varying levels of resistance, obviously depending on these neighbourhoods' bargaining power. Even in those cases where they are permitted to set up a facility in a neobohemian neighbourhood, it is common for brand name chains to be subject to a strict set of regulations, often imposed to limit their visibility and their ability to compete unfairly with lesser-known independent operators (Hinshaw, 2008). The bottom line, which the agents controlling these neighbourhoods recognize, is that if a chain company wishes to start up an operation in their midst it must comply to the local regulatory regime. In this way, we could argue that the forces of globalization, represented by the interests of the brand name chain, become contingent on local forces to a far greater extent than what is witnessed in conventional tourisin bubbles.

Concurrently, however, the very success of so many neo-bohemias nationwide means that despite their obvious resistance to standardized representations of global capital we are beginning to encounter increasing predictability in their offerings. This predictability is mirrored through the expected assemblage of Ethiopian, Thai, and Indian restaurants, boutique hotels and bed and breakfasts, microbreweries, independently-owned coffee houses and ice-cream parlours, as well as artists' studios and cinemas specializing in foreign movies. Meanwhile, the visitors to these areas who are initially drawn by their need to escape the drab standardization of the tourist bubbles (Judd, 2004) themselves become more standardized and conventional lending to a feeling that ultimately, these neobohemian environs may not be impervious to forces of growing homogeneity.

Further, Judd (2004) adds that even within these non-enclavic spaces, visitors and residents are subject to a barrage of regulations. The more popular they become as destmations, the more likely they are to encounter instruments of the revanchist city because, ultimately, public officials and private interests want to ensure removal of threatening elements to the users' experience. Such measures, ironically, likely ensure the very grittiness that initially served to put these places on the visitor map is eventually swept aside. On a broader front, they demonstrate that even though the energence of such neo-bohemias may be contingent on local bottom-up forces, these areas operate increasingly within the confines of the neoliberal agenda. What is more, the nature of these experiences necessitates the inposition of various inherent imequities. For example, the members of the creative class who live and work within the neo-bohemian areas and the visitors who frequent these districts depend on an army of lowly paid workers performing various functions of social reproduction. Despite the need for these workers' services the gentrification of the neo-Bohemian neighbourhoods and the rising cost of housing that goes with it mean that they also have no place within these areas once their shift is over. Just like the people who are kept out as a direct result of revanchist practices, these workers end up being outsiders.

\section{Conclusions}

The adoption of visitor-oriented projects as a means of revitalizing ailing cities has been a key strategy in the U.S. since the inception of the neoliberal era. In this essay we have highlighted how by the beginning of the 21 st century, downtown tourist enclaves represented the outcome of a blended form of neoliberalism, combining both characteristics of its original roll-back form with those of its rollout successor (Peck and Tickell, 2002). Particular places within American cities had, in effect, been transformed into fairly standardized visitor attractions through a form of governance, which (a) paid homage to incentive-driven private sector involvement while (b) local governments themselves adopted an increasingly revanchist role, aimed primarily at disciplining any elements (persons and activities) seen as threats to these areas' attraction.

To the casual observer the high level of predictability found in so many of these so-called tourist bubbles (Judd, 2004) generates the belief that neoliberalism is enforced everywhere in a non-malleable top-down manner, not allowing for local contingencies. However, it has been our main aim to demonstrate that this is, in fact, far from the case. We contend that, in reality, a multitude of varying forces shape the neoliberal approach as it becomes enmeshed within the local 
level. As Wilson (2004: 771) maintains neoliberal governances are "anything but a 'top-down' brute and desensitized imposition on cities" and can be "best conceptualized as a series of differentiated, keenly negotiating, procedural, and space mobilizing constructions".

Although we acknowledge that a handful of other observers have already remarked on neoliberalism' contingent nature our principal argument is that the best places to observe this contingency in action are the so-called neo-bohemian neighbourhoods (Lloyd, 2002) that have been emerging in more and more cities over the last few years. Places like Wicker Park in Chicago are transforming into popular points of visitor consumption while also attracting new residents precisely because they display elements of uniqueness setting them aside from the more predictable enclaves. In other words, these places draw more and more visitors who are becoming disillusioned with the standardization of the bubble (Judd, 2004).

Nevertheless, despite the fact some of these neo-bohemias may have begun as bottom-up initiatives and even though they may display a lot of elements of uniqueness in terms, for example, of the built environment or the locally owned businesses in their midst, we are aware that in many instances their transformation still operates within the realm of a city's neoliberal governance structure albeit one that is definitely shaped by local historical and geographical circumstances. Thus, we conclude that neo-bohemian neighbourhoods as places of visitor consumption have emerged as the perfect metaphor of neoliberalism's highly contingent nature.

\section{References}

Beauregard, R.A. (1998). Tourism and economic development policy in US urban areas. In D. Ioannides and K.G. Debbage (eds) The Economic Geography of the Tourist Industry: A Supply Side Analysis. London: Routledge, 220-34.

Bianchi, R.V. (2012). A radical departure: A critique of the critical turn in Tourism Studies. In J. Wilson (ed.) The Routledge Handbook of Tourism Geographies. London: Routledge, 46-54.

Brenner, N. and Theodore, N. (2002). Preface: From the "new localism" to the spaces of neoliberalism. Antipode, 34(3), 341-7.

Britton, S.G. (1991). Tourism, capital, and place: Towards a critical geography of tourism. Environment and Planning D: Society and Space, 9(3), 451-78.

Clancy, M. (1998). Commodity chains, services and development: Theory and preliminary evidence from the tourism industry. Review of International Political Economy, 5(1), 122-48.

Clark, T.N., Lloyd, R., Wong, K., and Jain, P. (2002). Amenities drive urban growth. Journal of Urban Affairs, 24(5), 493-515.

Daley, R.M. (2000). The Chicago Alternative Policing Strategy (CAPS). In P.J. Andrisani, S. Hakim, and E. Leeds (eds) Making Government Work: Lessons from America's Governors and Mayors. New York: Rowman \& Littlefield, $145-60$.

Debbage, K.G. and Ioannides, D. (2012). The economy of tourism spaces: A multiplicity of "critical turns". In J. Wilson (ed.) The Routledge Handbook of Tourism Geographies. London: Routledge, 149-56.

Elander, I. (2002). Partnerships in urban governance. International Social Science Journal, 54(172), 191-204.

Fainstein, S.S. (2010). The Just City. Cornell: Cornell University Press.

Fainstein, S.S., Hoffman, L.M., and Judd, D.R. (2004). Introduction. In L.M.Hoffman, S.S. Fainsteinand D.R. Judd (eds) Cities and Visitors: Regulating People, Markets, and City Space. Oxford: Blackwell, 1-19.

Florida, R. (2002). The Rise of the Creative Class and How it's Transforming Work, Leisure, Community and Everyday Life. New York: Basic Books.

Gillette, H. Jr. (2010). Is this the neoliberal moment? Journal of Urban History, 36(3), 393-7.

Giuliani, R.W. (2000). Reforıning New York City: A new chapter in reinventing government. In P.J. Andrisani, S. Hakim, and E. Leeds (eds) Making Government Work: Lessons from America's Governors and Mayors. New York: Rowman \& Littlefield, 161-6.

Gladstone, D. and Préau, J. (2008). Gentrification in tourist cities: Evidence from New Orleans before and after Hurricane Katrina. Housing Policy Debate, 19(1), 137-75.

Goldsmith, S. (2000). City services in the competitive marketplaces. In P.J. Andrisani, S. Hakim, and E. Leeds (eds) Making Government Work: Lessons from America's Governors ard Mayors. New York: Rowman \& Littlefield, 173-83.

Hackworth, J. (2007). The Neoliberal City: Governance, Ideology, and Development in American Urbanism. Ithaca, NY: Cornell University Press.

Hall, C.M. (2006). Urban entrepreneurship, corporate interests and sports megaevents: The thin policies of competitiveness within the hard outcomes of neoliberalism. Sociological Review, 52(s2), 59-70.

Hall, C.M. (2007). Tourism and regional competitiveness. In J. Tribe and D. Airey (eds) Advances in Tourism Research: New Directions, Challenges and Applications. Oxford: Elsevier, 217-30.

Hall, C.M. and Page, S.J. (2012). From the geography of tourism to geographies of tourism. In J. Wilson (ed.) The Routledge Handbook of Tourism Geographies. London: Routledge, 9-25.

Hinshaw, M. (2008). Great neighborhoods. Planning, 74(1), 6-11.

Hoffman, L.M., Fainstein, S.S., and Judd, D.R. (2004). Cities and Visitors: Regulating People, Markets, and City Space. Oxford: Blackwell Publishing.

Hoffman, L.M. (2004). Revalorizing the inner city: Tourism and regulation in Harlem. In L. Hoffiman, SS. Fainstain and D.R. Judd (eds) Cities and Visitors: Regulating People, Markets, and City Space. Oxford: Blackwell, 91-112. 
Ioannides, D. (2003), The economics of tourism in host communities. In S. Singh, D.J. Timothy and R.K. Dowling (eds) Tourism in Destination Communities. Wallingford: $\mathrm{CABl}, 37-54$.

Ioannides, D. and Debbage, K.G. (eds) (1998). The Economic Geogrophy of the Tourist Industry: A Supply Side Analysis. London: Routledge.

loannides, D. and Timothy, D.J. (2010). Towrism in the USA: A Spatial and Secial Synthesis. London: Routledge.

Jessop, B. (2002). Liberalism, neoliberalism, and urban governance: A statetheoretical perspective. Antipode, 34(3), 452-72.

Judd, D.R. (1995). Promoung tourism in US cities, Tutrism Management, $16(3), 175-87$.

Judd, D.R. (1999). Constructing the tourist bubble. In .R. Judd and S.S. Fainstein (eds) The Tour ist City. New Haven, CT: Yale University Press, 35-53.

Judd, D.R. (2004). Visitors and the spatial ecology of the city. In L. Hoffman, SS. Fainstain and D.R, Judd (eds) Cities and Visitors: Regulating People, Markets, and City Space. Oxford: Blackwell, 23-38.

Judd, D.R. (2006). Commentary: Tracing the commodity chnin of global tourism. Tourism Geographies, 8(3), 323-36.

Kastenbaum, S. (2012). NYPD's "stop, question and frisk" policy is racial profiling, critics say. CNN Online 3 April 2012. Available at http://inamerica. blogs.cnn.com/20 12/04/03/nypds-stop-question-and-frisk-policy-is-racialprofilingeritics-say/?hpt $=$ hp_c2 [6 April 2012].

Keil, R. (2002). "Common-sense" neoliberalistn: Progressive conservative urbanism in Toronto, Canada. Antipode, 34(3), 578-601.

Kotler, P., Haider, D.H, and Rein, I. (1993), Marketing Places. Attracting Investment, Industry, and Tourism to Cities, States, and Nations. New York: The Free Press.

Lloyd, R. (2002). Neo-bohemia: Art and neighborhood redevelopment in Chicago. Joumal of Urban Affairs, 24(5), 517-32,

MacLeod, G. (2002). From urban entrepreneurialism to a "revanchist city"? On the sputial injustices of Glasgow's Renaissance. Antipode, 34(3), 602-24.

Mosedale, J. (ed.) (2011). Political Economy of Jourism: A Critical Perspective. London: Routledge.

Peck, J. and Tickell, A. (2002), Neoliberalizing space. Ansipode, 34(3), $380-404$

Pierre, J. (2011). The Politics of Urban Governance. Basingstoke: Palgrave MacMillan.

Smith, N. (1998), Giuliani time: The revanchist 1990s. Social Texr 57, 16(4), $1-20$.

Smith, N. (2001). Global secial cleansing: Postliberal revanchism and the export of zero tolerance. Social Justice, 28(3), 68-74.

Smith, N. (2002). New globalism, new urbanism: Gentrification as global urban strategy. Antipode, 34(3), 427-50.
Sternberg, C.A. (2012). The Dynamics of Contingency: Ne liberal Redevelopment Governance in Chicago and Buenes Aires. PhD Dissertation submitted at University of Illinois at Urbana-Champaign.

Turner, R.S. and Rosentraub, M.S. (2002). Tourism, sports and centrality of cities. Journal of Urban Affairs, 24(5), 487-92.

Wilson, D. (2004). Toward a contingent urban neeliberalistn. Urban Geography, $25(8) .771-83$. 